\title{
The role of the pepenadores and their relationship to sustainable development: A proposal for municipalities
}

\section{El rol de los pepenadores y su relación con el desarrollo sustentable: Una propuesta para municipios}

\author{
MURRAY-NUÑEZ Rafael Martin†', OROZCO-BENITEZ, María Guadalupe and NÁJERA- \\ GONZALEZ, Oyolsi
}

Secretaria de Investigación and Posgrado, Universidad Autónoma de Nayarit

ID $1^{\text {st }}$ Author: Rafael Martín, Murray-Nuñez / ORC ID: 0000-0003-4095-1268, Cvu 410008

ID $1^{\text {st }}$ Coauthor: María Guadalupe, Orozco-Benitez / ORC ID: 0000-0001-8149-7650

ID $2^{\text {nd }}$ Coauthor: Ovolsi, Nájera-Gonzalez

DOI: $10.35429 / J M M E .2019 .5 .3 .14 .25$

Received July 20, 2019; Accepted December 10, 2019

\begin{abstract}
The problem of urban solid waste (RSU) is one of the concerns of contemporary society and a global challenge to public management, the transition from rural to urban, changed consumption patterns. This research aims to disseminate what occurs daily in solid waste landfills, and to publicize another vision regarding the final disposal of municipal solid waste, such as the municipality of Xalisco, Nayarit; in this regard, it is relevant to raise the work of the pepenadores in the framework of a formalized exercise, in which they are guaranteed equal opportunities, work-based remuneration, job stability, social security, training and Rest.
\end{abstract}

Pepenadores, Sustainable Development, Proposal

\begin{abstract}
Resumen
El problema de los residuos sólidos urbanos (RSU) constituye una de las preocupaciones de la sociedad contemporánea y un desafío mundial para la gestión pública, la transición de lo rural a lo urbano, modificó los patrones de consumo. La presente investigación tiene como objetivo divulgar lo que acontece a diario en los vertederos de residuos sólidos, y dar a conocer otra visión referente a la disposición final de los residuos sólidos municipales, como es el caso del municipio de Xalisco, Nayarit; en este sentido, es pertinente plantear la labor de los pepenadores en el marco de un ejercicio formalizado, en el que se les garantice la igualdad de oportunidades, la remuneración acorde al trabajo, la estabilidad laboral, la seguridad social, la capacitación y el descanso.
\end{abstract}

Pepenadores, Desarrollo sustentable, Propuesta

Citation: MURRAY-NUÑEZ Rafael Martin, OROZCO-BENITEZ, María Guadalupe and NÁJERA-GONZALEZ, Oyolsi. The role of the pepenadores and their relationship to sustainable development: A proposal for municipalities. RINOE JournalMacroeconomics and monetary economy. 2019. 3-5: 14-25.

\footnotetext{
$\dagger$ Researcher contributing first author.
} 


\section{Introduction}

Solid waste management (RS) problems, particularly their final disposal, can be considered from the time when human beings began to congregate in tribes, villages and communities. The accumulation of waste became a consequence of life, in remote times this did not pose a significant problem since the population was small and the amount of land available for the assimilation of waste was large (Careaga, 2000).

However, currently the problem of the generation of RS and its corresponding management and final disposition, does not escape any population in the world and is more acute in the large urban centers and growing cities. The majority of the population worldwide is concentrated in urban areas, presenting increasing challenges to solve the urbanenvironmental problems, especially in the metropolis as a result of a great acceleration in the urbanization initiated since the middle of the industrial revolution, that formed cities that were not prepared for the demographic explosion and its growth acquired a disorderly character (Jordan, 2003; SEDESOL, 2011; Aponte, 2007).

Mexico is a country with an urban population of $72 \%$, concentrated in 383 cities with more than 15,000 inhabitants. The current urban anomalous projection in the country is estimated to reach 121 million people in the next 18 years, who will live in urban areas with more than one million inhabitants in 2030 (SEDESOL, 2011).

Said growth and concentration will require various inputs for its maintenance such as water, energy and materials, as well as the adequate disposal of waste, where the inadequate discharge of RS in water and soil, alters the quality of these resources, as well as their impact on health Human and in ecosystems. Demographic growth, concentration in urban, metropolitan areas and productive methods have not complied with environmental regulations, to this it is possible to add the economic model that has a negative cause in the consumption habits of the population (De Valle, 2005; Zaman and Lehmann, 2011; Zaman, 2014; Vij, 2012). The issue of urban solid waste (MSW) is one of the concerns of contemporary society and a global challenge for public management (AIDIS, 2006).
This problem of the generation of MSW, where the highest levels correspond to countries with high economic income, as is the case in the North American region, consisting of Mexico, the United States and Canada (UNEP, 2004).

In Mexico, the transition from rural to urban, modified the consumption patterns of a society that mainly produces organic waste, to one that produces inorganic waste (IR) derived from the consumption patterns of urban industrial societies (SEDESOL, 2011) .

In 2010, the country generated 109,750 tons of RS daily, of which $64 \%$ were deposited in landfills, 9\% in landfills controlled, and the remaining $27 \%$ in open-air dumps. The third part of the RS ends in uncontrolled places, this practice has generated environmental problems that affect the health of the localities near the open air dumps (INEGI, 2010). In Mexico, the average daily RS per capita generation at $0.9 \mathrm{~kg}$, in rural areas with $0.4 \mathrm{~kg}$ and in cities of $1.5 \mathrm{~kg}$. (INE, 2010). The management of MSW in developing countries lies with the local authorities (Chen et al., 2010; Kanat, 2010; Okot-Okumo and Nyenje, 2011). The case of Mexico does not escape this condition, the "Political Constitution of the United Mexican States" indicates that it is the commitment of the municipal authorities to manage and collect them (SEDESOL, 2005).

However, in our country the management is insufficient due to the little progress that the landfill projects have had and their progress in the matter of legislation; product of the vision that was had on the RS and the lack of capacities to provide an adequate infrastructure, together with insufficient financial resources by the municipalities to address this problem (Gutiérrez, 2006; GTZ, 2003). The management of SR in our country has gone through three moments in its history: it begins in the year of 1964 with a focus on sanitary regulation, later in the years 1988 with the creation of national environmental legislation there is a basic management of waste, the last period in 2003, this was due to the creation of the General Law for the Prevention and Integral Management of Waste (DOF, 2003), this proposal goes beyond the previous ones, incorporating aspects of the sustainable management of MSW (Zaman and Lehmann, 2014; Ezeah and Roberts, 2014; Menikpura et al., 2013; Dálisa et al., 2012; Marshall and Farahbakhsh, 2013; Pires et al., 2011).

MURRAY-NUÑEZ Rafael Martin, OROZCO-BENITEZ, María Guadalupe and NÁJERA-GONZALEZ, Oyolsi. The role of the pepenadores and their relationship to sustainable development: A proposal for municipalities. RINOE Journal- Macroeconomics and monetary economy. 2019 
The separation of MSW is the commitment and responsibility of citizens that arises from the knowledge of the negative impacts produced by incorrect management of MSW. The formulation of comprehensive public policies for the benefit of recyclers, must be supported in the knowledge of the positive environmental impacts contributed by this activity and the dissemination of these among the whole society. In this way, it will be feasible to incorporate the collective, the authentic assessment by those who recycle materials.

In this sense, it is pertinent to consider the work of the recyclers in the framework of a formalized exercise, in which they are guaranteed equal opportunities, remuneration according to work, job stability, social security, training and rest necessary. Because the transport of the recovered materials represents a great cost in the process, it is essential that the institutions support initiatives aimed at modernizing motorized vehicles. The purpose of this research is to disseminate what happens daily in landfills and to publicize another vision regarding the final disposal of municipal solid waste, considering the area of influence of the elements involved and how to attack the origin of the conflict in The decrease of this problem.

From the experiences reviewed, it should be noted that in the municipality of Xalisco, Nayarit Mexico and in much of the country there are no recognition actions, creation of inclusion policies, in favor of the population of pepenadores. There is also a delay in efforts to dignify and recognize the economic and environmental benefits generated by the recycling activity of these groups; The municipal administration does not have a register of the people who work in the landfill, nor do fiscal control actions that prevent the participation of third-party personnel that have not traditionally exerted as a recycler ex officio. At present, the commercialization of recovered materials is linked to the needs of raw materials for the development of new products, so intervention from multilateral organizations is necessary, to create cooperation mechanisms that facilitate the articulation between groups of recyclers that inhabit near the garbage dump, to carry out activities that reduce the volume of inputs such as plastic bottles and contribute positively to avoid depletion of natural resources and the impact on the environment.

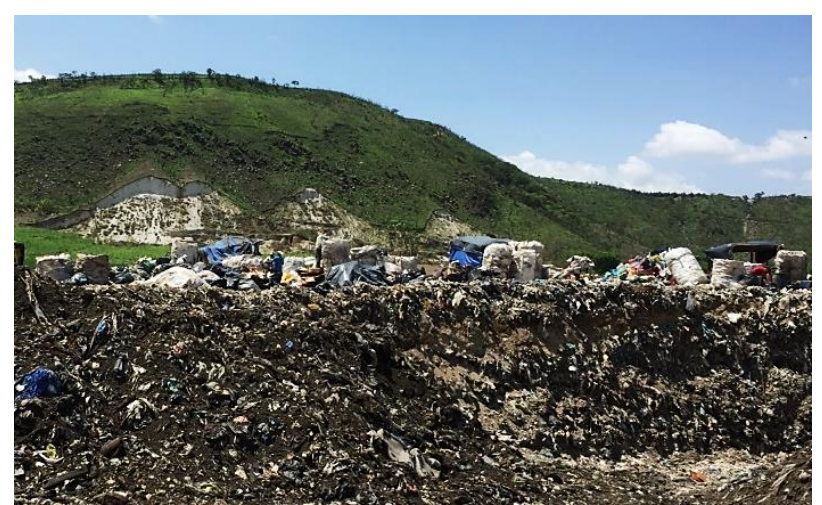

Figure 1 Separate and packed plastic bottles. Municipal landfill of Xalisco, Nayarit. Taken with mobile phone camera

An additional element is the role played by the global market context of recycled or recovered materials and their impact on the income level of recyclers. In this regard it is important to emphasize the need to articulate governments with research and society to develop research on alternative uses or conditioning, which allow a better use of materials with low demand in the market.

Regarding the participation of citizens, as an indispensable element for the correct separation at the source, the experiences reviewed demonstrate the need to raise awareness about the issue permanently and in the long term and even complement it with stimuli in the rate of provision of the cleaning service that motivates adherence to environmental sustainability practices.

In this sense, the dissemination of clear information on the environmental benefits that are perceived by waste management in an inclusion framework for waste pickers, results in the improvement of the living conditions of society in general, as a result of coherent policies with the social dynamics and the needs of the recycling population, in what would constitute an example of application of the premises of sustainable development.

Currently, you can see a larger picture of research on recycling and recyclers. It is possible to find research that includes the social, economic, environmental and health development context of recyclers, as well as analysis of municipal initiatives that have not addressed such problems in terms of public policies. 


\section{Explanation of the sections of the chapter}

Studies on recycling and recyclers have been developed over the past few years around various issues, including the environment of groups engaged in the recycling activity in terms of their social and economic context and the occurrence on their health, the interaction between municipal public policies NGOs and social organizations, the influence of the world economy on such activity and on recyclers considered within the lowest socioeconomic level and the incidence of such activities on sustainable development. Research trends account for the transformation of solid waste recycling issues, which at the beginning was restricted to the environmental impact of the recycling activity, without comprehensively addressing the consequences of the work of the pepenador of who exercise this activity of high degree of risk on the lives of the recyclers, from an integral perspective of sustainable development.

1. Waste pickers and their social and economic context.

In recent years, the growth of urban areas with the consequent displacement of inhabitants of rural areas throughout the world, has partly derived as a result of the poverty conditions that prevail this imposes the development model which focuses solely on the economic growth, and has influenced the emergence of the practice of collecting waste materials for marketing as a livelihood.

This activity, primarily carried out by marginal groups that embrace the possibilities offered by open-air dumps, causes the emergence of safety and protection networks among those who work in the trade.

When investigating the problem of the generation of SR in rural areas, it becomes clear how this process is inherent in the presence of humanity itself and the way it is associated with social organization and the concepts that have emanated collectively on the consumption, wellbeing, and the satisfaction of societyenvironment relationship needs.
Referring to the background, Medina (1999), recounts the practices of recycling materials in different eras and regions of the world: In Rome III and VI centuries BC. , bronze was recycled, in Mexico prior to the colony, wastes from human metabolism were recycled for use in agriculture; between the eleventh and eighteenth centuries in Spain, urine was recycled, for textile use in papermaking; between the seventeenth and mid-nineteenth centuries in Japan human feces was recycled as a fertilizer for agriculture.

Recycling has become an alternative for marginal groups of the population characterized by a low level of income, which are dedicated to the collection of materials in open-air dumps with commercialization possibilities and return to the productive cycle.

Its practice is a subsistence alternative for some segments of this population whose socioeconomic conditions are precarious. In this regard, Yepes (2005) states: "The factor that borders them is extreme poverty that forces many to be employed in recyclers or informal pepenadores in order to survive."

Hartman (2012) describes the conflicts that occur between the pepenadores or recyclers themselves in landfills in urban areas, who perform their work in an open-air sanitary landfill; Factors such as location and distances to materials define the occurrence of tensions among marginal people dedicated to this work.

It is for this reason that the recycling activity has been neglected by the government sector due to its direct impact on global trends that influence local actions; However, the majority of the population ignores the importance of the work of the recyclers and even hinders their performance.

Recycling activity prevails as a labor option in the so-called developing countries or with unstable economic systems such as our country, with marked socio-economic differences of low income among its inhabitants and which are referred to as "developing countries" (2011 ); Scheinberg and Anschütz (2005), researchers who highlight the need for RS reception transfer spaces for the community. 
Different studies carried out by OtengAbabio (2011) indicate the sectors in which there is efficiency in the management of MSW in conditions of poverty, while highlighting the environmental and economic impacts produced by the activity of the recyclers, to support the recycling processes and guarantee economic benefits. Hayami and Mishra (2006) expose the situation of the recyclers, highlighting their valuable contribution to society, highlight the environmental benefits of the economy by disposal costs in landfills and conservation of resources and indicate the way out of poverty through Public initiatives to improve their income level and quality of life, this warns about the low remuneration of workers in the landfills.

Bidegain (2011) determined that within the process involved in the activity of pepenadores they obtain the lowest economic benefits, Gill (2007), who studied the relationships between sellers (recyclers) and buyers, of recycled materials, denounces serious disadvantages in transactions.

Tahir and Tahir (2012) analyze the situation of the informal sector, especially for women, showing how the petty level of income and lack of studies, the lack of contraceptive methods, high birth rates and conditions of marginality, influence the Difficulty accessing decent and formal work. They are also considered in Bonner and Spooner (2011) who warn of the great opportunities that could arise for informal women recyclers under solidarity forms of organization.

In contrast to the reports where few investigations can be identified, it is the case of first world countries the level of middle and high income, as is the case in Canada, where Gutberlet, Tremblay, (2009) study the conditions of social marginality of the pepenadores, while highlighting the importance of offering them possibilities of inclusion through citizens' policies and participation.

In the same country, but in St. John's, Newfoundland and Labrador, Porter (2015), it is proposed to promote community interaction with the pepenadores, giving them the RS properly separated, as a condition that favors the process of inclusion of this population and that allows proper management of the MSW, this in our country is not carried out, instead the RSs collect in a general way in a truck.

\section{Global economy and its influence on recyclers}

The circumstances of the global economy have led to the mobilization of large segments of the population from rural areas to large cities. The low levels of schooling and income of those who arrive in the cities have generated the need to resort to the exercise of recycling as a form of livelihood.

Puncher (2005), describes how rapid population growth and the consequent generation of MSW are conditions for inhabitants in third world cities to devote themselves to recycling, as a form of livelihood; It also analyzes the difference between recyclers and buyers of materials and makes a characterization by income levels and sites of origin. Choudhary (2003) recommends ensuring adequate means of production, working conditions and stable union forms of organization.

Dimarco (2013) conducted a study regarding recycling focused on Latin America and refers to the importance that the issue of environmental impact, the changes produced from the market and the concept of trade in order to achieve dignification achieved in the last half century; Both situations affected the formation of recycling organizations, as well as groups that have gradually gained recognition.

Discarded materials such as RS and then recovered and recycled to return to the productive flow and the globalized market, are prioritized or rejected according to global fluctuations in supply and demand, which determines their price and high availability allows a place for mediation of the groups of pepenadores dedicated to the recycling RSU; An example of this, Nading (2011) mentions the influence of the market for aluminum recycling, as a raw material in the manufacture of soda and beer bottles. Grant and Oteng-Ababio (2016), describe the recycling of electrical and electronic equipment parts, called urban mining, as the activity that replaces the demand for raw materials in countries, which are dedicated to the manufacture of electronic devices such as computers. They propose a comprehensive sustainable system that facilitates the processes of exploitation and recovery of raw materials, based on a planned project for the recycling of devices and devices that facilitate the separation of essential materials to obtain their parts. 
Kuppinger (2013) describes the deterioration in the living conditions of the population of recyclers in the city, as a result of the implementation of MSW management designs.

\section{The Recycling Activity and Health Impacts}

In addition to market pressure, the development of the recycling activity leads to the exposure of various factors that intervene on the health of recyclers; Thus, the conditions in which the collection, separation and selection of recovered waste is traditionally carried out, influence the state of health and physical deterioration of the recyclers. Notably, the task of recycling is an activity that represents occupational hazards due to postures, exposure to substances, increased exposure to diseases, occurrence of injuries and in many cases, working between heavy machinery Gutberlet and Baederb (2008).

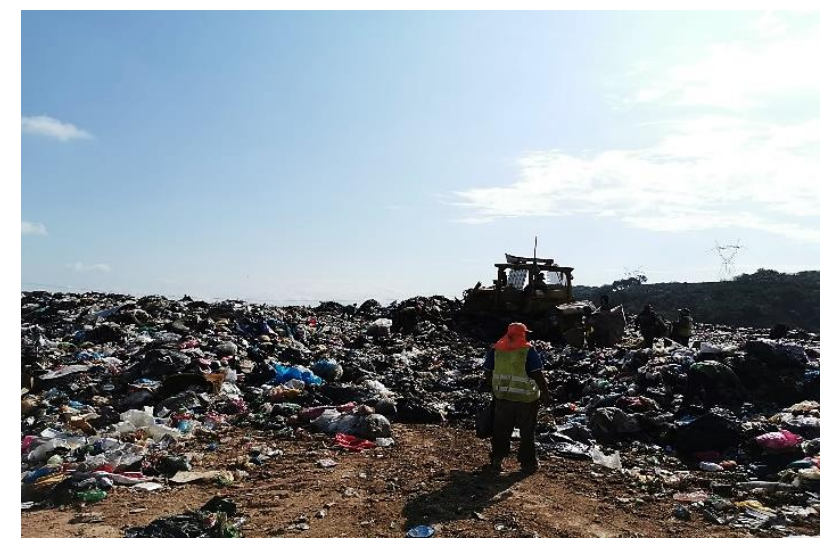

Figure 2 Occupational risk in the landfill. Municipal landfill of Xalisco, Nayarit. Taken with mobile phone camera

In the same vein, Alvarado et al (2008) refer to how recyclers represent a population whose activity invariably exposes them to the Toxoplasma Gondi parasite, the effect of eating contaminated food and low education conditions to avoid contracting it. Vearey (2011) analyzed HIV AIDS carriers, who have migration patterns and in many cases, end up carrying out the recycling activity as a livelihood.

\section{Sustainable Development and Recycling}

Sustainable development was defined as "one that guarantees the needs of the present, without compromising the possibilities of future generations to meet their own needs" (Brundtland Commission, 1987,).
The recycling activity is consistent with this concept: the return of materials to the production cycle, avoiding the consumption of resources, favoring the integration of marginal recyclers into the economic model. In this regard, Roberts (2004), highlights the importance of sustainable strategies, for excluded workers, such as pepenadores, who become workers in environmental services, through the management of MSW.

This position is associated with the approach of Ciplet (2014), who emphasizes the right to recognition that marginalized recyclers have (women, pepenadores and indigenous people). For its part, De Medeiros, (2012), defends recycling as an activity of sustainability to the consumption model of today's society, highlighting environmental benefits.

\section{Benefits of recycling waste materials}

Several authors have made inquiries in which, based on the reality of the recyclers and based on the clarification of the aspects that must change in the welfare conditions, they have disclosed the positive environmental impacts of the recycling exercise.

From the environmental approach, the recycling (collection, transport and final disposal) of raw materials by the use of material prepared for reuse, increased the useful life of the equipment used by the managers of MSW, this it causes the increase of the useful life of the landfill, and the reduction of contaminants in soil and water that are generated in case of a misuse of MSW (Sepúlveda, 2003).

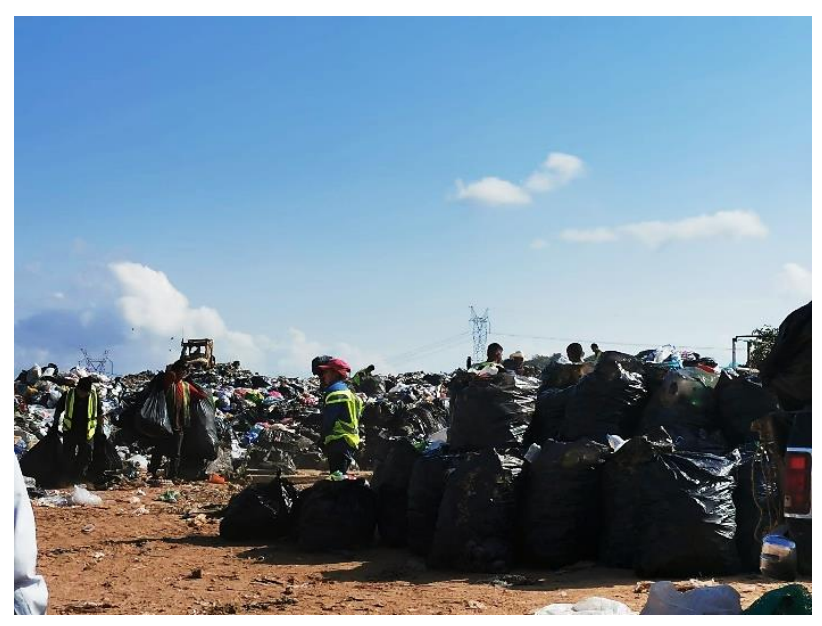

Figure 3 Bottle and PET recycling product. Take with mobile phone camera 
In the same investigation, a characterization is made about income, previous work and family group; raising the need to assume forms of organization that allow benefits for those who perform this trade.

\section{Recycling: Public policy and social organizations}

The intervention of the state in the creation of conditions that benefit the recognition of the groups of recyclers for the positive impact at economic and environmental level of the activity that they carry out, is incipient and referred to the incidence in the formulation of public policies with approaches that are adjust to exposed diagnoses from the understanding and clarity about the exercise of recycling.

Sepúlveda (2003) shows how the figures that reveal poverty reduction between the decades of the 1970s and 1990s in Latin America are followed by a high degree of income inequality. It presents the need for an excessive share of solidarity towards the pepenadores by the society and to set up diagnoses from all dimensions that affect the recycling work. The aspects cited by Corredor (2010) that are decreasing the profits of the recuperators are, among others, the absence of a set of techniques aimed at improving this work and the lack of social work programs in relation to the recycling of landfills.

In other scenarios, Terraza (2009) assumes what is necessary to intervene for the benefit of the groups of recyclers; for execution and technical preparation that supports the correct measures regarding waste management; the scarce coverage for areas far from the cities, and identifies them as their great weaknesses in the issue of final disposal and zero minimization, informal separation and limited recycling. The professionalization of the recycler trade, based on better living conditions for recyclers, would be a solution for obtaining clean cities, are the proposals of Scheinberg and Anschütz (2005), in what they call ecological and environmental modernization of the RSU in developing countries, in order to achieve sustainability. Bonner and Spooner (2011), suggest partnerships between informal recyclers and Non-Governmental Organizations (NGOs) to achieve recognition of the work of the pepenadores to improve their working conditions.

\section{Methodology to be developed}

The analysis was carried out in the municipality of Xalisco, Nayarit; where the landfill of this town is currently one of the solid waste concentration points, which, as in the rest of the country, does not have a good organization, therefore the management of these is unconventional and inappropriate, since only The municipal government is limited to transferring them to an open-air dump without having any infrastructure or respecting the current legislation, depositing them in these places without mediating the impact that the waste can cause on the environment.

In this paper some of the conceptualizations about conditions in which the work of the pepenadores or recyclers of plastic and paper bottles, leaving evidence of the economic and environmental benefits are related. It was developed from searches of scientific articles in databases in the Spanish and English languages, with the greatest number of documents prevailing; field work and visits to the landfill in the years 1999 to 2019 in which 52 tons of daily waste are generated. The purpose was to review the issue of recyclers, landfills, landfills and open-air dumps, from the various approaches that are related to the concept of sustainable development.

Once the scientific consultation texts were chosen, we proceeded to group them by countries with topics relevant to recyclers. In this way the categories listed with the titles of the present work were defined, a coincidence was built between the investigations of the landfills and recyclers and the themes or methodologies used, however, the coincidences were not those expected for their different cultural and sociolevel generalizable economics between different countries on the issue of recycling. (Example: Pepenator and recycler is the name assigned depending on the socioeconomic level of the country in question).

In general, it is noted in all the articles and writings reviewed, a trend that integrates the benefits of this type of work with the exhortation to promote conditions of life improvements for the pepenadores who have traditionally performed this difficult job of recycler. 
Initially, the data of some researchers related to the condition how the trade is performed, the level of income of the recyclers and their direct relationship with the association of different recycled materials in the productive cycle of supply and demand within the market are presented. The document presents some research directed from the perspective of occupational health and occupational hazards of recyclers, caused by the activity of recycling without adequate equipment and protocols within a sanitary landfill.

Since sustainable development is an institutionally accepted concept worldwide, although on a smaller scale depending on the different societies, it is tried to expose the essential idea of optimizing current resources to guarantee their access to future generations, it is materialized and exemplifies recycling within landfills implemented under parameters of social cohesion, equity, and environmental responsibility. The benefit of recycling addresses the level of progress in the formulation of public policies, as well as interventions from the perspective of trade union and social organizations. The trends that are considered, allow to define some necessary inputs to exercise the job of recycler as an activity focused in an integral way, which positions the human being as an actor of an alternative development form framed in sustainable development.

\section{Process of formalizing the population of the Recycler}

The proposed study highlights the importance of effectively containing the population of pepenadores in the management of urban waste, which has a remarkable performance in the open air dumps of the city Xalisco, Nayarit in which they have not promoted legislation that integrates and includes these workers gradually, they are granted rights, benefits and recognition. The groups of RSU material pepenadores should be included in the processes for the management of solid waste in the municipality. The decision originates in response to a lawsuit that claims to be disadvantaged to participate as providers, in front of traditional grooming organizations.
The objectives of the different administrations for the fulfillment of the requirements can be summed up in: incorporating the citizenship through permanent training about the recycling process; definition of areas for service provision; adequacy of collection points and inclusion of the population of recyclers. Pepenadores' right to health and legal benefits, particularly with the agreement to have social security and be willing to pay taxes, all as a new demand for the lack of inclusion of recyclers in the service delivery process Toilet.

\section{Pepenadores participate in} environmental services, favor the decrease of the volume of sanitary landfills of the municipality giving them a longer life, this intervention is by workers (pepenadores) in the Municipality of Xalisco, Nayarit, Mexico.

\section{Conclusions}

The research on recycling and the different theoretical approaches, indicate in the first instance that the process of selecting, collecting, transporting, classifying, marketing the discarded materials so that they are returned to the productive cycle, is carried out in a pyramid scheme, in which the recyclers-pepenadores constitute the lower level on which the whole process is supported. Then marginal population groups are involved and work characterized by low cultural levels, income, poor school education and socio-economic situation of exclusion as a livelihood alternative.

The articulation between government, in its role of formulator of public policies and entities such as NGOs in their function of proposing alternatives for sustainable development, enable the contribution of recyclers and identify elements that contribute to the improvement of their quality of life. This will be achieved in fair working conditions, with a higher level of income and access to better markets.

Likewise, training in business management, the appropriate conditions regarding occupational health, inclusion within the communities, the best locomotion, articulation with traditional waste management systems and the role in public policies contribute to this end. 
In experience, the population is unaware of the problem of workers who work in sanitary landfills and open-air dumps, it is perceived by the majority of society ignorance of the benefits that recyclers bring to the environment, economic and social. This reality translates into the lack of support for the basic exercise of separation at the source, which constitutes the first link in the efficient recycling chain, which hinders the task of the recycler, reduces the availability of materials and contributes to the depletion of resources. natural.

The formulation of comprehensive public policies for the benefit of recyclers, should be supported in the knowledge of the positive environmental impacts contributed by thisactivity and dissemination of these among the entire society. In this way, it will be feasible to incorporate the collective, the authentic assessment and appreciation for those who recycle materials.

In this sense, it is pertinent to consider the work of the recyclers in the framework of a formalized exercise, in which they are guaranteed equal opportunities, remuneration according to work, job stability, social security, training and rest necessary. For its part, the municipality of Xalisco, is presented as a municipality without proposals on waste management, without the participation of recyclers, however, it is necessary to implement fiscal control actions that prevent the participation of people who have not traditionally exercised as a trade recycler and do not pay taxes, which are intended to be passed as recyclers.

Since the commercialization of recovered materials is linked to the needs of raw materials for the development of new products, it is necessary the intervention of multilateral organizations to create cooperation mechanisms that facilitate the articulation between groups of recyclers around the planet, which in turn allows to meet the demand for inputs and contribute positively to avoid the depletion of natural resources and the impact on the environment produced by their extraction.
Regarding the participation of citizens as an indispensable element for the correct source separation, the experiences reviewed demonstrate the need to raise awareness on the subject permanently and in the long term and still complement it with stimuli in the rate of provision of the cleaning service that motivate adherence to environmental sustainability practices. In this sense, the dissemination of clear information on the environmental benefits perceived by a waste management in an inclusion framework for the recyclers-peelers, it would result in the improvement of the living conditions of society in general, as a result of policies consistent with the social dynamics and needs of the recycling population, in what would constitute an example of application of the premises of sustainable development.

\section{References}

Alvarado, C., Liesenfeld, O., Márquez, J., Cisneros A, Estrada, S., Martínez, S., y Corral, N.(2008). Seroepidemiology of Infection with Toxoplasma gondii in Waste Pickers and Waste Workers in Durango, Mexico. Zoonoses and Public Health, 55, 306-312. doi: 10.1111/j.1863-2378.2008.01133.x.

Aponte, F. A., (2007). La sustentabilidad urbana en las ciudades, Boletim Goiano de Geografía Goiânia: 27 (2), 11-33.

Asociación Interamericana de Ingeniería Sanitaria y Ambiental - AIDIS, Directrices para la Gestión Integrada y Sostenible de Residuos Sólidos Urbanos en América Latina y el Caribe/Asociación Interamericana de Ingeniería Sanitaria y Ambiental - AIDIS y Centro Internacional de Investigaciones para el Desarrollo - IDRC, São Paulo (2006), http://www.aidis.org.br/PDF/libro_residuos_sol idos.pdf Acceso: 20 de Septiembre (2013).

Bidegain, N. (2011). Hacia una gestión integrada de los residuos con inclusión social.

Recomendaciones para la acción. Centro interdisciplinario de Estudios sobre el desarrollo - Uruguay.

Bonner, C., y Spooner, D. (2011). Organizing Labour in the Informal Economy: Institutional Forms \& Relationship. Labour, Capital and Society, 44 (1). 
Careaga. J. (2000). Residuos sólidos: Propuesta para una Política Nacional.Gaceta Ecológica Num 36 Septiembre de 1995.

Ciplet, D. (2014). Contesting Climate Injustice: Transnational Advocacy Network Struggles for Rights in UN Climate Politics. Global Environmental Politics $14 \quad$ (4). doi:10.1162/GLEP_a_00258.

Cisse, O. (2005). The Segmentation and Growth Factors of the Informal Solid Waste Recovery Activities in Dakar (Senegal). Waste the social context, (125 - 139). Alberta Canada: Edmonton.

Corredor, M. (2010). El Sector Reciclaje en Bogotá y su Región: Oportunidades para los negocios Inclusivos. Serie Guías sectoriales. Fundes.

Chen, X., Y. Geng, T. Fujita, (2010). An overview of municipal solid waste management in China, Waste Management: 30, 716-724.

Choudhary, B. (2003). Waste and WastePickers. Economic and Political Weekly, 38 (50), 5240-5242.

Dálisa, G., M.F. Di Nola, M. Giampietro, (2012). A multi-scale analysis of urban waste metabolism: density of waste disposed in Campania, Journal of Cleaner Production: 35, 59-70.

De Valle, G, (2005). La Gestión Integral Sustentable de residuos sólidos urbanos: Diagnóstico y evaluación para la ciudad de Saltillo, Coahuila. El Colegio de México, México, D.F.

De Medeiros C, De Carvalho A y Azevedo J. (2012). Gerenciamento dos resíduos sólidos do município de natal/rn: caracterização das cooperativas de catadores. Monografias Ambientais. 10(10), 2220 - 2234.

Dimarco, S. (2013). Trabajo, desarrollo y clasificación de residuos: transformaciones en el último medio siglo. Estudios Sociológicos, 31(91), 203-228.

Ezeah, C., C.L. Roberts, (2014). Waste governance agenda in Nigeria cities: a comparative analysis, Habitat International: 41, 121-128.
Gill, K. (2007). Interlinked Contracts and Social Power: Patronage and Exploitation in India's Waste Recovery Market. Journal of Development Studies, 43(8), 1448-1474.

Gonçalves, D., y Dutra, I. (2015). The influence of trust in the constitution of a brazilian cooperative of selectivewaste pickers. R. Adm. Faces Journal Belo Horizonte, 15(1), 25-43. ISSN 1984-6975 (online). ISSN 1517-8900 (Impressa).

GTZ, (2003). La Basura en el Limbo: Desempeño de Gobiernos Locales y Participación Privada en el Manejo de Residuos Urbanos, México, D.F., Comisión Mexicana de Infraestructura Ambiental/ Agencia de Cooperación Técnica Alemana (GTZ). http://www2.gtz.de/dokumente/bib/070126.pdf.

Grant, R y Oteng-Ababio, M. (2016). The Global Transformation of Materials and the Emergence of Informal Urban Mining in Accra, Ghana. Africa Today, 62(4). doi:

10.2979/africatoday.62.4.01

Gutiérrez, V., (2013). Diagnóstico Básico para la gestión integral de residuos,

Gutberlet, J., Tremblay; C., Taylor, E.; Divakarannair, N. (2009). Who are our informal recyclers? An inquiry to uncover crisis and potential in Victoria, Canada. Local Environment, 14(8), 733-747.

Gutberlet, J., Baederb, A. (2008). Informal recycling and occupational health in Santo Andre', Brazil. International Journal of Environmental Health Research, 18(1), 1-15. doi: 10.1080/09603120701844258.

Hartman, C. (2012). Uneven Urban Spaces: Accessing Trash in Managua, Nicaragua. Journal of Latin American Geography, 11 (1).

Hayami, J., Dikshit, A., y Mishra, S. (2006). Waste Pickers and Collectors in Delhi: Poverty and Environment in an Urban Informal Sector. Journal of Development Studies, 42(1), 41-69. doi: 10.1080/00220380500356662.

MURRAY-NUÑEZ Rafael Martin, OROZCO-BENITEZ, María Guadalupe and NÁJERA-GONZALEZ, Oyolsi. The role of the pepenadores and their relationship to sustainable development: A proposal for municipalities. RINOE Journal- Macroeconomics and monetary economy. 2019 
INE, El manejo de los residuos sólidos urbanos y de manejo especial en México, México. D.F., Instituto Nacional de Ecología (2005), http://www2.inecc.gob.mx/publicaciones/libros/ 495/residuos.html.

INE, Generación y composición de los residuos sólidos municipales, En Reporte del estado ambiental y de los recursos naturales en la frontera norte de México por SEMARNAT, pp 191-199, México, D.F., (2010), http://www2.inecc.gob.mx/publicaciones/downl oad/109.pdf.

INEGI, Residuos: Recolección y disposición final de residuos sólidos urbanos, 1998 a 2010 (2010),

http://app1.semarnat.gob.mx/dgeia/informe_04/ pdf/cap8.pdf.

Kanat, G., (2010).Municipal solid-waste management in Istanbul, Waste Management: 30, 1737-1745.

Kharvel, R., (2012). Sustainable Solid Waste Management in India, Master thesis, Department of Earth and Environmental Engineering, Columbia University, New York, U.S.A . http://www.seas.columbia.edu/earth/wtert/sofos /Sustainable\%20Solid\%20Waste\%20Managem ent\%20in\%20India_Final.pdf.

Kuppinger, P. (2013). Crushed Cairo's garbage collectors and neoliberal urban politics.

Journal of urban affairs, 36(S2), 621-633. doi: 10.1111/juaf.12073

Leuenberger, D. y Wakin, M. (2007). Sustainable Development in Public Administration Planning: An Exploration of Social Justice, Equity, and Citizen Inclusion. Administrative Theory \& Praxis, 29 (3), 394411.

Lohri, C.R., E.J. Camenzind, C. Zurbrügg, (2014). Financial sustainability in municipal solid waste management - Costs and revenues in Bahir Dar, Ethiopia, Waste Management: 34(2), 542-552.

Marshall, R.E., K. Farahbakhsh, (2013). Systems approaches to integrated solid waste management in developing countries, Waste Management: 33, 988-1003
Marshall, R.E., K. Farahbakhsh, (2013). Systems approaches to integrated solid waste management in developing countries, Waste Management: 33, 988-1003.

Menikpura, S.N.M., J. Sang-Arun, M. Bengtsson, (2013). Integrated solid waste management: an approach for enhancing climate co-benefits through resource recovery, Journal of Cleaner Production: 58, 34-42.

Nading, A. (2011). Foundry Values: Artisanal Aluminum Recyclers, Economic Involution, And Skill in Periurban Managua, Nicaragua. Urban Anthropology and Studies of Cultural Systems and World Economic Development, 40(3/4) Approaches to Informal Economies, 319-359.

Okot-Okumu, J., R. Nyenje, (2011). Municipal solid waste management under descentrlisation in Uganda, Habitat International: 35, 537-543.

Oteng-Ababio, M. (2011). Missing links in solid waste management in the Greater Accra Metropolitan Area in Ghana. GeoJournal, 76(5), 551-560.

Pires, Ana, G. Martinho, N. Chang, (2011). Solid waste management in European countries: A review of systems analysis techniques, Journal of Environmental Management: 92, 1033-1050.

Porter, M. (2015). Marginal recycling: place and informal recycling in St. John's,

Newfoundland. Local Environment, 20(2), 149164. doi: 10.1080/13549839.2013.836162.

Puncher, C. (2005). A socio-economic study of waste pickers and itinerant buyers in Phnom Penh, Cambodia, waste the social context. Edmonton waste management centre of excellence.

Roberts, P. (2004). Wealth from waste: local and regional economic development and the environment, The Geographical Journal, 170 (2), 126-134.

Scheinberg, A. y Anschütz, J. (2005). Slim Pickin's: Scavengers and Waste Pickers In The Modernisation Of Urban Waste Management Systems In The South. Waste The social context. Alberta, Canada. Edmonton. 
Scheinberg, A., y Anschütz, J. (2006). Slim pickin's: Supporting waste pickers in the ecological modernization of urban waste management systems. International Journal of Technology Management and Sustainable Development. 5(3) doi:10.1386/ijtm5.3.257/1.

SEMARNAT-INE, México, D.F., (2006), http://www2.inecc.gob.mx/publicaciones/downl oad/495.pdf.

Sepúlveda, L.A. (2003). Balance y pertinencia del reciclaje de residuos sólidos residenciales con recicladores organizados en los centros urbanos de Colombia. Caso Medellín. Recuperado de http://www.bvsde.paho.org/bvsacd/cd51/balanc e.pdf el 24 de abril de 2012 de Base de Datos Repidisca.

SEDESOL. (2001). Problemática del tiradero a cielo abierto. En SEDESOL, Manual Técnico Administrativo para el Servicio de Limpia Municipal (págs. 33-41). D.F.

SEDESOL, Estado de las Ciudades de México 2011, México, D.F., Secretaria de Desarrollo Social-Programa de las Naciones Unidas para los Asentamientos Humanos, ONU-HABITAT (2011),

http://www.onuhabitat.org/index.php?option=c om_docman\&task=doc_details\&gid=583\&Item id $=330$.

Tahir, P., y Tahir, N. (2012). Is Informal Sector Employment Marginal to Formal Sector

Growth. The Pakistan Development Review, 51(4), 543-563.

Terraza, H. (2009). Manejo de residuos sólidos. Lineamientos para un servicio integral, sustentable e inclusivo.

http://idbdocs.iadb.org/wsdocs/getdocument.asp $\mathrm{x}$ ?docnum $=2197909$.

Trejo, R (1997). Procesamiento de la Basura Urbana. Trillas México 13 pp.

UNEP, Emerging issues in our global environment (en línea), Nairobi, Kenya, United Nations Environment Programme (2012). http://www.unep.org/yearbook/2012/pdfs/UYB _2012_FULLREPORT.pdf.
Vearey, J. (2011). South African HIV/AIDS programming overlooks migration, urban livelihoods, and informal workplaces. African Journal of AIDS Research, 10(supplement), 381-391doi: 10.2989/16085906.2011.637741.

Vij, D., (2012).Urbanization and solid waste management in India: present practices and future challenges, Procedia Social and Behavioral Sciences: 37, 437-447

Yepes D. (2005). Alternativas para el fortalecimiento del reciclaje informal en Medellín. Tesis de Maestría Universidad Nacional de Colombia -sede, Medellín, Colombia. Recuperado de: http://www.iadb.org/es/temas/residuossolidos/iniciativa-regionalpara-la-inclusion-derecicladores, $4918 . \mathrm{html}$

Zaman, A.U., (2014).Measuring waste management performance using "Zero Waste Index": the case of Adelaide, Australia, Journal of Cleaner Production: 66, 407-419.

Zaman, A.U., S. Lehmann, (2011). Urban growth and waste management optimization towards 'zero waste city', City, Culture and Society: 2, 177-187.

Zaman, U. (2016). A comprehensive study of the environmental and economic benefits of resource recovery from global waste management systems. Journal of Cleaner Production, 124, 41-50. 